\title{
Wave Regime and Lithodynamics in the Region of the Western Crimea Accumulative Coasts
}

\author{
Yu. N. Goryachkin*, V. V. Fomin \\ Marine Hydrophysical Institute of RAS, Sevastopol, Russian Federation \\ *yngor@yandex.ru
}

\begin{abstract}
Purpose. The paper is aimed at obtaining the wave regime characteristics in the region of the Western Crimea accumulative coast, at constructing the scheme of the sediment along-coastal fluxes for various wind directions, at analyzing the previous notions on the lithodynamical processes in the region under study and their comparison with the obtained results.

Methods and Results. The wave regime was analyzed using the results of the retrospective calculations of wind waves in the Black Sea derived due to the model SWAN and based on the ERAInterim atmospheric reanalysis data for 1979-2018. The data of retrospective calculations performed by the method of annual maximums yielded the parameters of the waves of various repeatability. The sediment along-coastal flux was simulated and the schemes for six wind directions were constructed by the method including model values of the wave characteristics.

Conclusions. Operative and extreme characteristics of the wind waves in the region under study are obtained. It is shown that in the above-mentioned area, the most intense sediment along-coastal fluxes occur being affected by the waves formed by the western, southwestern and southern winds. The northwestern and western winds give rise to the sediment main flux directed to the east. At the western wind, to the southeast from the Donuzlav sandbar and in the coast concavities, the sediments are transported in the opposite direction. When the winds are southwestern and southern, the sediment along-coastal flux move from the Cape Uret to Lake Donuzlav northern spit, where it meets the oppositely directed flux. To the southeast from Lake Donuzlav, the multidirectional fluxes arise; at that, in the coast concavities their convergence zones are formed. At the southeastern and eastern winds, the sediment along-coastal fluxes' capacity decreases sharply; the fluxes are of multidirectional character and they form not a single flux on any of the long stretches of the coastline.
\end{abstract}

Keywords: wind-wave regime, lithodynamics, mathematical modeling, Crimea, Lake Donuzlav.

Acknowledgements: the research was carried out within the framework of the state task of Marine Hydrophysical Institute of RAS (theme No. 0827-2018-0004) at the RFBR support (project No. 18-05-80035).

For citation: Goryachkin, Yu.N. and Fomin, V.V., 2020. Wave Regime and Lithodynamics in the Region of the Western Crimea Accumulative Coasts. Physical Oceanography, [e-journal] 27(4), pp. 415-429. doi:10.22449/1573-160X-2020-4-415-429

DOI: $10.22449 / 1573-160 X-2020-4-415-429$

(C) Yu. N. Goryachkin, V. V. Fomin, 2020

(C) Physical Oceanography, 2020

\section{Introduction}

Accumulative coasts of the Western Crimea stretch from Lake Kyzyl-Yar to Lake Donuzlav (Belyaus area). Cape Yevpatoriysky divides them into two equal parts, about $37 \mathrm{~km}$ long each. The eastern part of this coast in terms of recreational and economic terms has already been largely developed (for example, the resorts of Evpatoria and Saki). Consequently, as a result of unreasonable economic activities, its beaches have significantly lost their former attractiveness [1]. The western part largely remains in its natural state and only in recent years has begun to attract the attention of investors. Here, the first steps have already been taken towards 
the coast development, which have caused deep concern among the public of local coastal settlements, rightly fearing the degradation of another section of the Crimean coast. There is a plan involving a continuous embankment construction throughout the area, including in the Saki region development strategy, as well as other equally ambitious plans. However, no scientific justification for such projects has been carried out yet.

At this point, one of the unresolved issues is the clarification of the scheme of the bottom sediment dynamics on a segment of the Lake Donuzlav - Yevpatoria coastline. Both its features and variability due to the impact of winds of different directions and the resulting flow are unknown. Meanwhile, this issue is fundamental both from the viewpoint of the territory development and from the standpoint of the constantly raised problem - the effect of sand mining in Lake Donuzlav and operation of the approach channel to the region coastal zone. Closely related to this issue is the problem of quantitative determination of wind-wave characteristics. At the closest to the area Yevpatoria hydrometeorological station, observations of the wind waves parameters are carried out during daylight hours by a visual method in a half-closed (from the western and southwestern directions of waves) bay. Therefore, such data can hardly be considered representative. To a certain extent, this also applies to data on wind, measured in conditions of dense urban development, as indicated in [2]. In connection with the plans for the development of the coast and the development of specific projects, the present study seems relevant.

The paper is aimed at obtaining the wave regime characteristics in the region of the Western Crimea accumulative coast, at constructing the scheme of the sediment along-coastal fluxes for various wind directions, at analyzing the previous notions on the lithodynamical processes in the region under study and their comparison with the obtained results.

\section{Wave regime}

One of the most important factors determining the lithodynamics of the accumulative coast of the Western Crimea is the wind waves of the Black Sea. To assess the wave regime of the considered area, the results of retrospective calculations of wind waves applying the Simulating Waves Nearshore (SWAN) spectral model [3] were used. They were based on the numerical solution of the following wave energy balance equation

$$
\frac{\partial}{\partial t} N+\frac{\partial}{\partial x}\left(c_{x} N\right)+\frac{\partial}{\partial y}\left(c_{Y} N\right)+\frac{\partial}{\partial \sigma}\left(c_{\sigma} N\right)+\frac{\partial}{\partial \theta}\left(c_{\theta} N\right)=S / \sigma,
$$

where $N=E / \sigma$ is the wave effect density, $E$ is the wave energy spectrum; $x, y$ and $t$ are spatial coordinates and time; $\sigma, \theta$ are frequency and angular coordinates; $c_{X}, c_{Y}, c_{\sigma}, c_{\theta}$ are transfer speeds of along spatial and frequency-angular coordinates; $S$ are wave energy sources and sinks.

At the SWAN input ERA-Interim near-surface wind fields (URL: http://www.ecmwf.int (accessed: 15.07.2020)) for 1979-2018 were set. As a result of numerical modeling, an array of wind wave parameters was obtained on an unstructured grid for the entire Azov-Black Sea basin with a time discreteness 
of $1 \mathrm{~h}$ (further ERAI-SWAN array). Details of the wave fields calculation are presented in [4]. From this array, four grid nodes closest to the area under study were selected (Fig. 1), and series of wind speed $(w)$ and direction $(\varphi)$ of the significant waves height $\left(h_{s}\right)$, of the mean wave direction $(\theta)$, of the mean $(\bar{\tau})$ and peak periods $\left(\tau_{p}\right)$ of waves lasting 40 years were formed.

The series obtained are characterized by the following maximum values: $\max w=24.5-25.9 \mathrm{~m} / \mathrm{s} ; \max _{s}=6.5-7.8 \mathrm{~m} ; \max \bar{\tau}=11.2-11.4 \mathrm{~s}$. The longterm mean values of $w$ and $h_{s}$ for points $1-4$ are $7.25 \mathrm{~m} / \mathrm{s}$ and $0.77 \mathrm{~m}$, respectively.

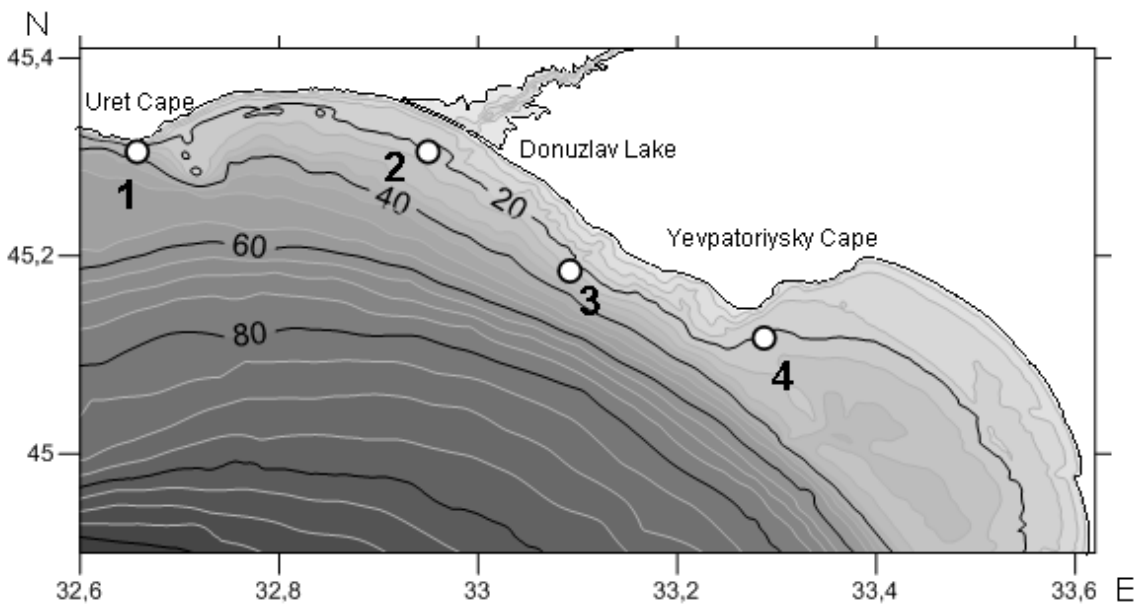

F i g. 1. Bottom relief (m) on the area under study (point 2). White circles - location of the points where the data from the ERAI-SWAN array were analyzed

The analysis showed the ERAI wind characteristics at points 1-4 of the study area to have insignificant differences.

As can be seen (Fig. 2, a), from the sea side, the southwestern wind has the highest frequency $(6 \%)$. The distribution of long-term mean values of wind speed by directions shows the same tendency (Fig. 2, b) - from the sea side, the highest wind speeds correspond to the southwest direction.
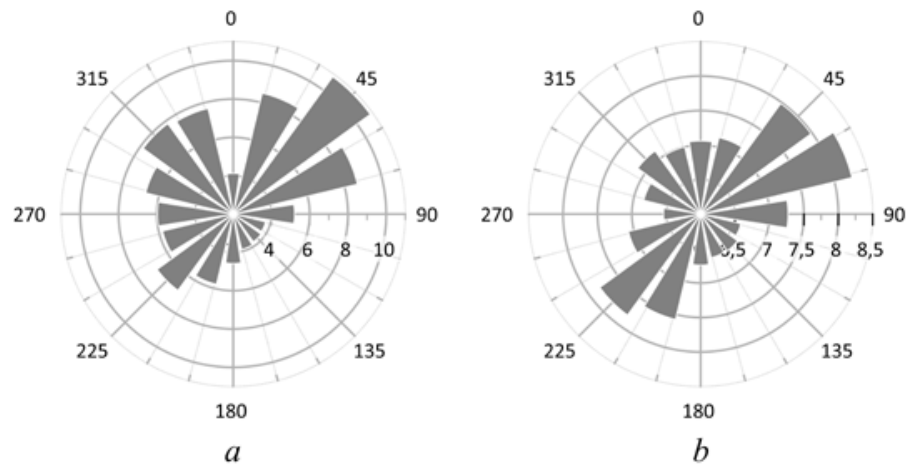

F i g. 2. Wind characteristics from the $E R A I$ data in point 3: $a$ - repeatability of wind directions (\%); $b$ - distribution by directions of the mean multi-year values of wind speed $(\mathrm{m} / \mathrm{s})$ 

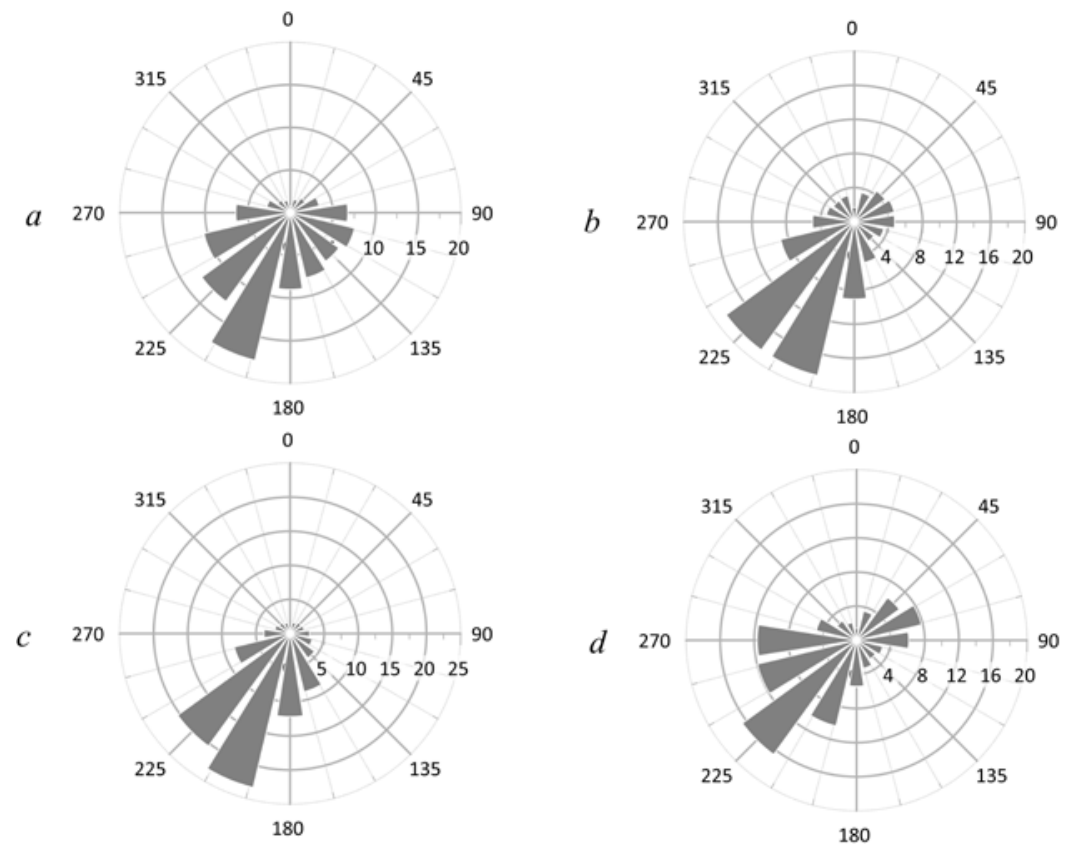

F i g. 3. Repeatability the mean wave direction (\%) based on the ERAI-SWAN data: $a$ - in point $1 ; b-$ in point $2 ; c-$ in point $3 ; d-$ in point 4
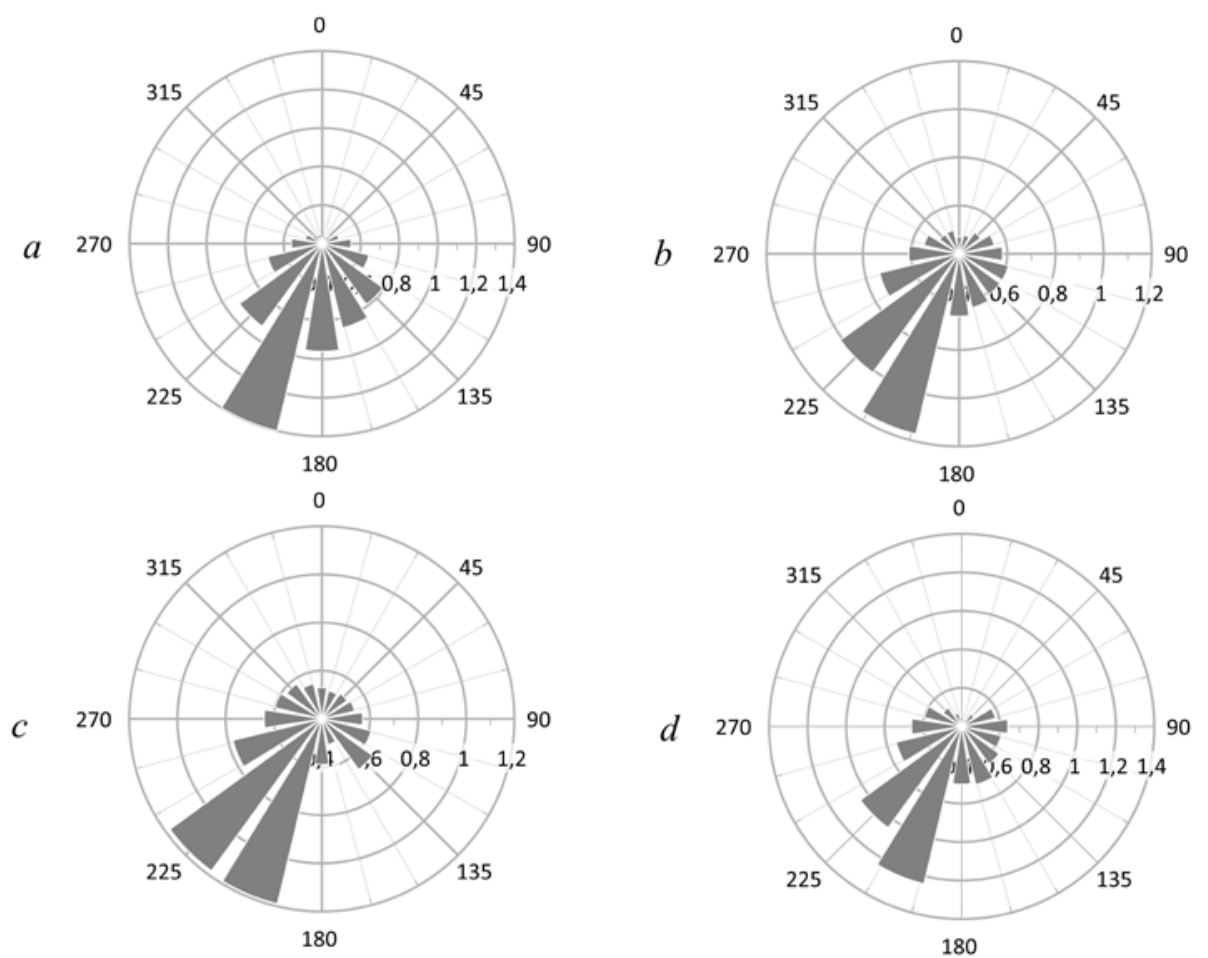

F i g. 4. Distribution by directions of the mean multi-year values of the significant wave heights (m) based on the ERAI-SWAN data: $a$ - in point $1 ; b$ - in point $2 ; c$ - in point $3 ; d-$ in point 4 
Waves' mean height $\bar{h}$, mean period $\bar{\tau}$, and mean length $\bar{\lambda}$; significant wave heights $h_{s}$, and wave heights with 50\%-, $13 \%-, 3 \%$ - and $1 \%$-cumulative probability in points 1-4 occurring once per 1, 5, 10, 25 and 50 years

\begin{tabular}{|c|c|c|c|c|c|c|c|c|}
\hline$T$, year & $\bar{h}, \mathrm{~m}$ & $\bar{\tau}, \mathrm{s}$ & $\bar{\lambda}, \mathrm{m}$ & $h_{s}, \mathrm{~m}$ & $h_{50 \%}, \mathrm{~m}$ & $h_{13 \%}, \mathrm{~m}$ & $h_{3 \%}, \mathrm{~m}$ & $h_{1 \%}, \mathrm{~m}$ \\
\hline \multicolumn{9}{|c|}{ Point 1} \\
\hline 1 & 2.9 & 9.2 & 114 & 4.7 & 2.8 & 4.5 & 5.7 & 6.5 \\
\hline 5 & 3.6 & 10.1 & 130 & 5.9 & 3.5 & 5.5 & 6.9 & 7.7 \\
\hline 10 & 3.9 & 10.6 & 139 & 6.4 & 3.8 & 5.9 & 7.5 & 8.4 \\
\hline 25 & 4.3 & 11.2 & 149 & 7.0 & 4.2 & 6.5 & 8.2 & 9.1 \\
\hline 50 & 4.6 & 11.6 & 156 & 7.5 & 4.5 & 7.0 & 8.7 & 9.7 \\
\hline \multicolumn{9}{|c|}{ Point 2} \\
\hline 1 & 2.8 & 9.1 & 110 & 4.5 & 2.7 & 4.4 & 5.5 & 6.2 \\
\hline 5 & 3.4 & 10.0 & 125 & 5.4 & 3.3 & 5.2 & 6.6 & 7.4 \\
\hline 10 & 3.7 & 10.5 & 133 & 5.9 & 3.6 & 5.7 & 7.1 & 8.0 \\
\hline 25 & 4.1 & 11.1 & 142 & 6.5 & 4.0 & 6.2 & 7.7 & 8.6 \\
\hline 50 & 4.4 & 11.5 & 149 & 7.0 & 4.3 & 6.6 & 8.2 & 9.1 \\
\hline \multicolumn{9}{|c|}{ Point 3} \\
\hline 1 & 3.2 & 9.3 & 124 & 5.2 & 3.1 & 5.1 & 6.4 & 7.3 \\
\hline 5 & 3.9 & 10.1 & 142 & 6.4 & 3.8 & 6.1 & 7.7 & 8.7 \\
\hline 10 & 4.3 & 10.6 & 151 & 7.0 & 4.1 & 6.6 & 8.4 & 9.4 \\
\hline 25 & 4.7 & 11.1 & 162 & 7.7 & 4.6 & 7.3 & 9.1 & 10.3 \\
\hline 50 & 5.0 & 11.5 & 171 & 8.2 & 4.9 & 7.7 & 9.7 & 10.9 \\
\hline \multicolumn{9}{|c|}{ Point 4} \\
\hline 1 & 2.7 & 9.1 & 108 & 4.4 & 2.6 & 4.1 & 5.2 & 5.9 \\
\hline 5 & 3.3 & 10.1 & 124 & 5.4 & 3.2 & 5.0 & 6.3 & 7.0 \\
\hline 10 & 3.5 & 10.6 & 132 & 5.7 & 3.5 & 5.4 & 6.8 & 7.6 \\
\hline 25 & 3.9 & 11.2 & 141 & 6.4 & 3.8 & 5.9 & 7.4 & 8.3 \\
\hline 50 & 4.2 & 11.6 & 149 & 6.8 & 4.1 & 6.3 & 7.9 & 8.8 \\
\hline
\end{tabular}

Fig. 3 shows the frequency diagrams of the mean wave direction at points 1-4. It is seen that at points 1-3 the most probable direction of wave approach to the coast is the southwest and south-southwest, at point 4 - the southwest and westsouthwest. These wave direction repeatability maxima are caused by the wind direction repeatability, distribution of depths, as well as the influence of refraction, which, when approaching the coast, forces the wave fronts to orient parallel to the isobaths.

According to fig. 4, it can be concluded that the most wave-hazardous directions for the area under study are the southwest and south-southwest.

To assess the extreme characteristics of wind waves in the considered area, the method of annual maxima was used [5]. In the Table, for each point, the parameters of waves from the system of storms of different recurrence are given ( $\mathrm{T}$ is the return period of the storm). These data characterize the wave regime 
at a depth of $\sim 20 \mathrm{~m}$ and can be used as input information in the design of coastal protection structures and calculations of changes in the configuration of the coastline in the area under study. As can be seen, for storms that are possible once a year, the values $h_{s}$ are $4.4-5.2 \mathrm{~m}$. The values of the maximums $h_{s}$ in the initial series show that the known extreme storm on November 11, 2007 can be classified as a storm that is possible once every 25 years.

\section{Analysis of existing ideas about lithodynamics of the area under study}

The study of the coastal area under consideration began in August 1945 with an expedition from the Laboratory of Oceanology, subsequently reorganized into the Institute of Oceanology of the USSR Academy of Sciences. This is where regular scientific research of the sea shores in the USSR, and then in the Russian Federation, began. However, there are relatively few scientific publications devoted to this area. The description of the barrows of the numerous salt lakes on this coast was first given in [6]. The first results of the coast structure study and considerations on their possible dynamics, obtained from the aforementioned expedition data, are given in [7, 8]. Subsequently, a summary of the research carried out in 1945-1949 was published [9]. In the 60s of the last century there was an overpass built aimed to study the processes in the coastal zone in the Lake Donuzlav area. Using the data obtained there, in [10] the vertical distribution of concentration and the composition of suspended sediments in the wave destruction zone was considered. In [11] the dynamics of the relief of the underwater coastal slope, composed of shell material, was discussed. Based on long-term observations during field practice at the Faculty of Geology and Geography, Odessa University n.a. I. Mechnikov in [12], the revealed patterns of morphology and dynamics of the coast of the Western Crimea, including the area under study, are presented. The most complete information on the natural conditions and interannual variability of the coastline is given in recent works [1, 13], where geological and geomorphological conditions are considered in detail. Below the most important features that are important for further analysis are noted.

Modern lithodynamic processes on the coast are represented by bottom and coastal abrasion and displacement, erosion and accumulation of sediments. Their intensity is mainly determined by the wave regime and intensity. A strip of sandy beaches stretches along the entire coast of the region. Their typical width on the lake shores decreases in the southeast direction. The largest geomorphological form of the coast is the Donuzlav sandbar about $10 \mathrm{~km}$ long, which, after the canal was dug in its body (1962), was divided into southern and northern spits. The maximum thickness of sediments is observed here (shell sands with an admixture of oolites, gravel of bedrock limestone rocks and quartz grains).

Sediments of the coastal area between Lake Donuzlav and Cape Yevpatoriysky form beaches and cover the upper part of the underwater slope. It is an accumulative zone in which the flow is mostly saturated. At Cape Yevpatoriysky, it reaches the $2 \mathrm{~m}$ depth, expands towards Lake Donuzlav and reaches the $8 \mathrm{~m}$ isobath. Typical length of sands at the bottom in the area of the southern spit of Lake Donuzlav is up to $300 \mathrm{~m}$ from the shoreline, near Cape Yevpatoriysky - 10-20 m. At the sandbars of lakes, the length of the sands sharply increases to $1.0-1.5 \mathrm{~km}$ and, as shown by satellite images, changes little over time [13]. 
Deeper the accumulative zone, the sediments concentrate only in the limestone slab depressions, and even deeper they are absent altogether, and accordingly, their flow is absent. This feature is closely related to the bottom surface slope. As was shown in [9], at the 0.003-0.007 slopes (which are predominantly observed in the area under study), sediments are thrown ashore, and accumulation occurs only in a narrow coastal strip. It is no coincidence that the accumulation zone is expanding in the area of salt lakes, where relief depressions can be traced also at the bottom.

Currently, there are several existing schemes of sediment dynamics in the studied area. For the first time such a scheme was proposed by V. P. Zenkovich [7]. He pointed out that in the area of the Tarkhankutskiy Peninsula - Cape Uret (Oirat), the bedrock surface is rather strongly inclined. The coast forms high cliffs and is slowly abraded, in this case, all the sediments go to the bottom. To the east, between Cape Uret and Lake Donuzlav, the slopes are decreasing, and the bedrock surface is significantly lowered. Abrasion here occurs faster, but high cliffs are not formed, and the sea "cuts" an insignificant layer of rock. Sometimes pebble, sometimes sandy beaches are created along the coast. Over Lake Donuzlav conditions are dramatically changing, the bedrock surface slope is very small. The coast is not abraded at all and turns into an accumulative one. A rather powerful accumulation of sands was formed in the coastal zone. The study indicates that the source of the sands is the underwater slope of the coast from Cape Yevpatoriysky to Lake Donuzlav, where the sediment flow is directed from east to west, the counter flow is directed from Cape Uret to Lake Donuzlav. Later V.P. Zenkovich revised his viewpoint. In [9], he confirms that the origin of the sands is still beyond doubt, but at the present time (50s of the $20^{\text {th }}$ century) there are no signs of a modern significant movement of sediments in the Cape Uret - Cape Yevpatoriysky section. It is also noted here that the bedding of sediments is in equilibrium with the hydrodynamic regime, which does not exclude their two-sided short-term migrations. It seems important to conclude that the current supply of sediments is extremely small, and most part of the sands entered earlier epochs in the process of movements from the east from Cape Yevpatoriysky.

Yu. D. Shuiskiy [12] determined the directions of alongshore energy flows for 5 characteristic points of the coast, from Cape Yevpatoriysky to Cape Tarkhankut, based on the Knaps wave energy method [14]. These calculations showed that, on average, over a long-term period (1946-1976) in the direction from Cape Tarkhankut to Cape Yevpatoriysky, a gradual increase in the resulting vector of wind-wave energy occurred. A similar dependence was obtained for the "surf force", reflecting the frontal wave action degree. There was no prevalence of transverse or longitudinal sediment movement. An almost 4-fold increase in alongshore nanomotive force in this direction was also noted. It indicates a pronounced transfer of energy from Cape Uret to the Lake Donuzlav bay and further - to Cape Yevpatoriysky. The range of migration to Cape Yevpatoriysky increases 2.6 times.

Yu. D. Shuiskiy notes that the new scheme differs from that of V. P. Zenkovich, however, in his opinion, has a greater reliability, as it is largely confirmed by the structure of the relief and the distribution of the grain size and mineralogical composition, particularly, the nature of the distribution of 
terrigenous and carbonate sediments. In addition, a series of wind data with a duration of 30 years was used in the calculations. The flow capacity was estimated to be small - about several tens of thousands of cubic meters per year, as a result of that the region is characterized by a lack of sediment.

In his later work [20], the same author singles out a lithodynamic cell located from Cape Uret to Cape Yevpatoriysky, where about 60 thousand $\mathrm{m}^{3} /$ year of sediments, mainly shells, enter the coastal zone. Calculation of the alongshore energy flow direction showed that from Cape Uret it is directed towards the Lake Donuzlav bay. In the direction of this sandbar, the resulting flow is also directed at the section of Cape Yevpatoriysky - the Lake Solyonoe lagoon sandbar (to the west of Cape Yevpatoriysky). From it, part of the sediments in secondary movements during the action of western and northwestern disturbances (about $15 \%$ in total) can bend around Cape Yevpatoriysky and penetrate into the bay of the same name to the Yevpatoria commercial port pier. The author leaves the question of the integral direction of sediment transport in the Cape Yevpatoriysky - Lake Donuzlav section open.

The wind-wave method was used by E.I. Ignatov to calculate the direction of the total energy flows [15]. As a result, the characteristics of energy triangles and the resulting wind-wave energy vector, indicating the relative annual reserves of such energy on average over a long-term period, were obtained. The reserve value the increases from Cape Tarkhankut to the Lake Donuzlav bay from 9 to 10 conv. Units. Further to the southeast, it decreases to 6-7 conv. units and up to does not change up to Cape Yevpatoriysky.

Alongshore sediment-moving force within the area between Cape Tarkhankut and the Lake Donuzlav sandbar is a positive value and is directed to the east. To the east, alternation of vector directions is noted, while the absolute values do not exceed 3 conv. units for the shores exposed to the southwest, and 5 conv. Units - for the shores of the southern exposure. In the area east of Cape Yevpatoriysky, the sediment-moving force intensifies and forms a flow directed towards Cape Karantinniy. The author concludes: the alongshore flow is directed eastward from Cape Tarkhankut to the Lake Donuzlav bay (northern spit), where the zone of convergence with the southeastern flow appears. From the Lake Donuzlav sandbar (southern spit) up to Cape Yevpatoriysky the flow becomes unstable and is divided into several lithodynamic cells with convergence areas located at the sandbars.

\section{Modeling of sediment flux for different wind directions}

Numerical modeling of wind waves, wave currents and sediment flux in the coastal zone of the area under study was carried out in three stages. At the first stage, for a given wind field, the wave characteristics were calculated using the SWAN model. In order to improve the accuracy of calculations, we used a twostep method of nested grids. At the first step, the waves were modeled for the entire Azov-Black Sea basin with $4.5 \mathrm{~km}$ (point 1) horizontal resolution. Next, we calculated the waves in point 2, shown in Fig. 1, with $200 \mathrm{~m}$ horizontal resolution. At the liquid boundary of point 2, the SWAN results obtained for point 1 were applied. The model resolution in the angular coordinate was $10^{\circ}$, the frequency interval was $0.04-2 \mathrm{~Hz}$. 
At the second stage, in point 2 the wave currents caused by wave stresses $\left(\tau_{x}, \tau_{y}\right)$ were determined on the basis of shallow water equations numerical solution

$$
\begin{gathered}
\frac{\partial u}{\partial t}+u \frac{\partial u}{\partial x}+v \frac{\partial u}{\partial y}+g \frac{\partial \eta}{\partial x}+\frac{\tau_{x}}{H}=0, \quad \frac{\partial v}{\partial t}+u \frac{\partial v}{\partial x}+v \frac{\partial v}{\partial y}+g \frac{\partial \eta}{\partial y}+\frac{\tau_{y}}{H}=0, \\
\frac{\partial \eta}{\partial t}+\frac{\partial}{\partial x}(H u)+\frac{\partial}{\partial y}(H v)=0, \\
\tau_{x}=-\frac{\partial S_{x x}}{\partial x}-\frac{\partial S_{x y}}{\partial y}, \quad \tau_{y}=-\frac{\partial S_{x y}}{\partial x}-\frac{\partial S_{y y}}{\partial y},
\end{gathered}
$$

where $u, v$ are the depth-averaged horizontal current velocity components; $\eta$ is the sea level; $S_{x x}, S_{x y}, S_{y y}$ are the components of the radiation stress tensor [17] determined through the significant wave heights and the mean wave direction from the SWAN model.

At the third stage, using the Mikhinov - Ivanov method [18, 19], the vector components of specific sediment discharge $\left(q_{x}, q_{y}\right)$ were calculated in point 2 . The components of the wave current velocity $u, v$ from model (2) - (4), as well as $h_{s}, \theta, \bar{\tau}$ from the SWAN model (formula (1)) were used as the input data. It was assumed that the bottom in the coastal zone of the area under study is composed of medium-sized sand with $0.5 \mathrm{~mm}$ median diameter of [20].

In order to simplify the interpretation of the simulation results, the wind was preset as uniform in space and constant in time. The calculations were carried out for 6 wind directions (north-west, west, south-west, south, south-east, east) and three velocity values: $7.5 ; 10 ; 15 \mathrm{~m} / \mathrm{s}$. In all variants of calculations the wind action duration was 1 day, which corresponds to the typical duration of storms in this area.

It was found that for the indicated wind velocities, the results of model calculations do not differ qualitatively. Therefore, we will consider in more detail the results for a wind velocity of $15 \mathrm{~m} / \mathrm{s}$. In Fig. 5 and 6 the diagrams of sediment transport in the study area for different wind directions are given. In Fig. 7 and 8 the spatial distribution of specific sediment discharge $q=\sqrt{q_{x}^{2}+q_{y}^{2}}$, which characterizes the intensity of alongshore fluxes is shown.

Analysis of the modeling results showed that at a north-western wind (Fig. 5, $a ; 7, a$ ) in the coastal zone of the area under consideration, the bottom material moves towards east. At the same time, the consistent along-coast sediment flux throughout the entire region does not occur. Local material transport can be traced near Cape Uret. The values $q$ are $50-60 \mathrm{~g} / \mathrm{m} / \mathrm{s}$ here. There is also a slight material transport along the northern spit of Donuzlav Lake $(q \sim 50 \mathrm{~g} / \mathrm{m} / \mathrm{s})$. On the coastal zone section from the southern edge of Donuzlav Lake sandbar to Cape Yevpatoriysky, a consistent sediment flux is formed. Here, at 3-5 m depths, $q$ values increase 30 times and reach $1.5-2 \mathrm{~kg} / \mathrm{m} / \mathrm{s}$. In the area of $10-15 \mathrm{~m}$ isobaths $q$ values decrease to $50 \mathrm{~g} / \mathrm{m} / \mathrm{s}$. 


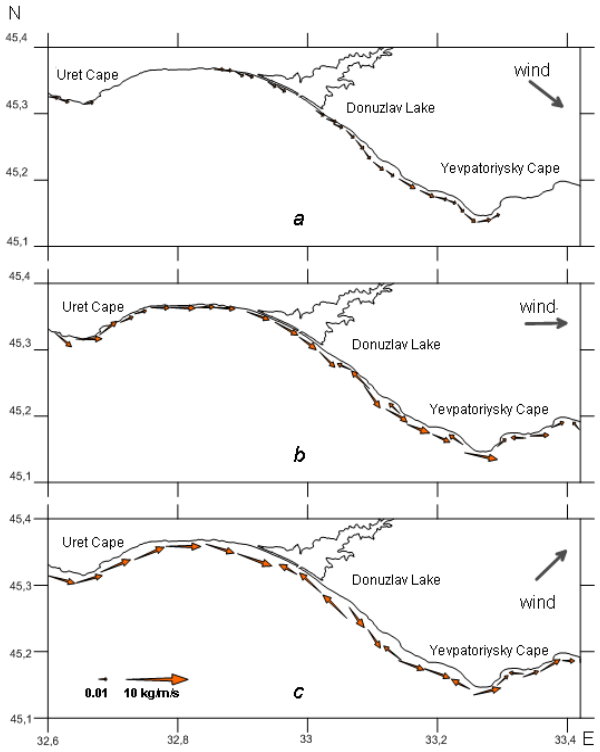

F i g. 5. Distribution of the sediment specific load vector at the northwestern $(a)$, western $(b)$ and southwestern (c) winds with the $15 \mathrm{~m} / \mathrm{s}$ speed

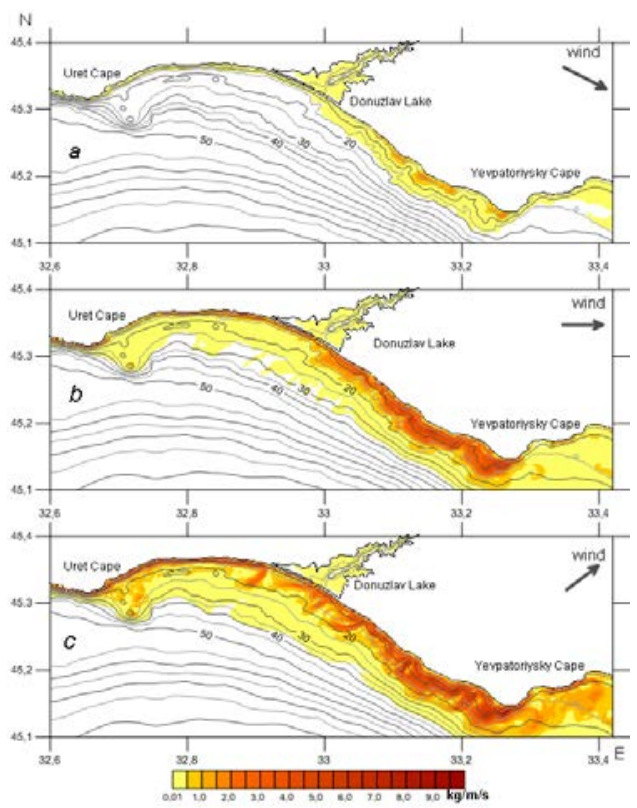

F i g. 7. Distribution of the sediment specific load vector $q$ at the northwestern $(a)$, western $(b)$ and southwestern $(c)$ winds with the $15 \mathrm{~m} / \mathrm{s}$ speed

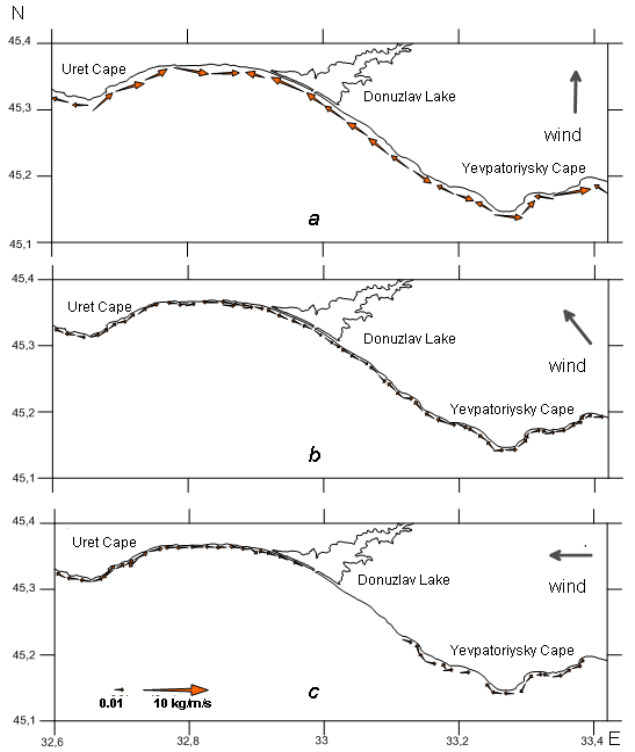

F i g. 6. Distribution of the sediment specific load vector at the southern $(a)$, southeastern $(b)$ and eastern (c) winds with the $15 \mathrm{~m} / \mathrm{s}$ speed

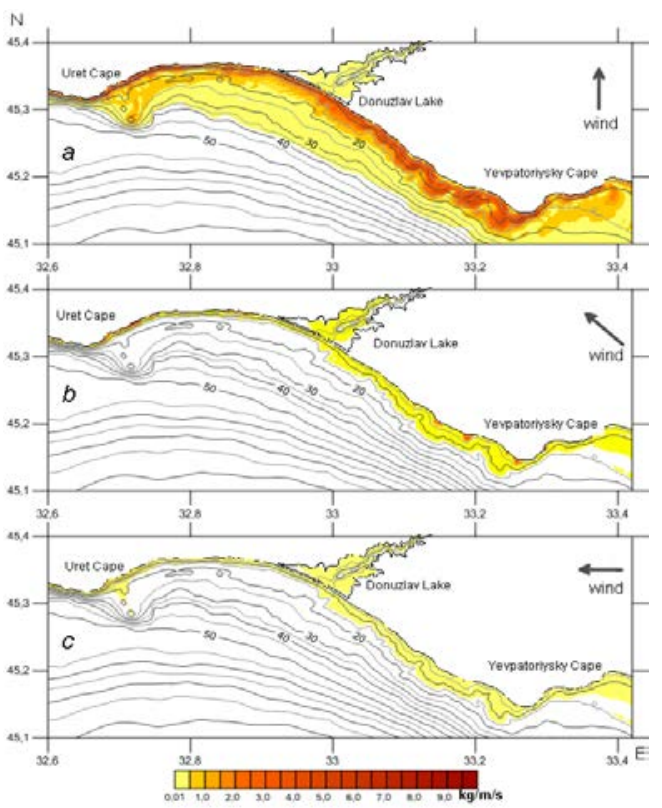

F i g. 8. Distribution of the sediment specific load vector $q$ at the southern $(a)$, southeastern $(b)$ and eastern (c) winds with the $15 \mathrm{~m} / \mathrm{s}$ speed 
At the western wind (Fig. 5, $b ; 7, b$ ), a general sediment flux, directed to the east, is formed. At the same time, to the southeast of Lake Donuzlav sandbar in the concavities of the coast, the material transport occurs in the opposite direction. Our observations show that in this case, the coastal ridges, attached to the coastline, located perpendicular or at some angle to the coastline [12], sometimes temporarily appear there. Eastwards of Cape Yevpatoriysky the sediment flux weakens. The main movement of bottom material transport takes place down to 10-15 m depths along the entire section from Cape Uret to Cape Yevpatoriysky. The maximum computational values of $q$ under effect of the western wind reach $5-6 \mathrm{~kg} / \mathrm{m} / \mathrm{s}$ at the coastal ledges. At the same time, a decrease in $q$ at the concavities is observed, which contributes to the material deposition in them and, in general, to the coastline straightening.

At the southwestern wind (Fig. 5, $c ; 7, c$ ), the alongshore sediment flux is directed from Cape Uret to the northern spit of Lake Donuzlav, where it meets the flux of the opposite direction. Eastward of Lake Donuzlav, multidirectional alongshore flows appear. At the same time, the zones of their convergence are formed in the concavities of the coast. The material is displaced to $20 \mathrm{~m}$ depth along the entire section from Cape Uret to Cape Yevpatoriysky with $q$ values within the range of $1-4 \mathrm{~kg} / \mathrm{m} / \mathrm{s}$. At the coastal ledges westward of Cape Yevpatoriysky, $q$ reaches 5-6 kg/m/s. Eastward of Cape Yevpatoriysky, $q$ values sharply decrease to $0.5 \mathrm{~kg} / \mathrm{m} / \mathrm{s}$ in the area of the Mainaki sandbar, and increase again to $3-6 \mathrm{~kg} / \mathrm{m} / \mathrm{s}$ further to the east.

At the southern wind (Fig. 6, $a$; 8, a), several zones where the flows move in various directions are distinguished in the structure of alongshore sediment flows. Two largest streams (one - from Cape Uret, the other - from Vitino) meet westward of Lake Donuzlav sandbar near Belyaus natural boundary. In the eastern part, like under the southwestern wind effect, multidirectional sediment flows with convergence zones in the coastal concavities are formed. For the considered wind direction, the values of $q$ make up, on average, $3-5 \mathrm{~kg} / \mathrm{m} / \mathrm{s}$.

At southeastern and eastern winds (Fig. 6, $b, c ; 8, b, c$ ), the thickness of the alongshore sediment flows sharply decreases. They have multidirectional movement, without forming a single flow on any extended section of the coastline. The characteristic $q$ value is $50-60 \mathrm{~g} / \mathrm{m} / \mathrm{s}$. At eastern wind, significant coastal areas are in wave shadow. As in other cases, a characteristic feature here is the formation of the convergence zones of flows in the coast concavities and divergence zones in its ledges. In the area of Lake Donuzlav entrance channel under the action of the southeastern wind, the sediment flows diverge in opposite directions.

Comparative analysis of numerical modeling results indicate that the most intense sediment flows in Cape Uret - Cape Yevpatoriysky area arise under the effect of waves formed by winds of the western, southwestern and southern directions. Since the winds and waves of the southwestern direction are the most frequent, then the scheme of sediment movement shown in Fig. 5, $c$ is the most characteristic pattern.

The main material transport takes place down to 10-15 m depths. For the most wave-hazardous wind directions in the west - south sector, the model values of PHYSICAL OCEANOGRAPHY VOL. 27 ISS. 4 (2020) 
the specific sediment discharge are: at a wind velocity of $7.5 \mathrm{~m} / \mathrm{s}-10-25 \mathrm{~g} / \mathrm{m} / \mathrm{s}$ (at the coastal ledges $50-100 \mathrm{~g} / \mathrm{m} / \mathrm{s}$ ); at a wind velocity of $10 \mathrm{~m} / \mathrm{s}$ the sediment discharge rate is $200-400 \mathrm{~g} / \mathrm{m} / \mathrm{s}$ (at the coastal ledges $700-800 \mathrm{~g} / \mathrm{m} / \mathrm{s}$ ); at a wind velocity of $15 \mathrm{~m} / \mathrm{s}-1-4 \mathrm{~kg} / \mathrm{m} / \mathrm{s}(5-6 \mathrm{~kg} / \mathrm{m} / \mathrm{s})$. An increase in the values of the sediment flow discharge on the underwater slope opposite the coastal protrusions and their decrease near the concavities leads to the material transport and deposition in the coastal zone of the latter.

Comparison of the obtained schemes of sediment movement with the previously existing ones, analyzed above, shows that the representations presented by E.I Ignatov in [15] are the closest to the typical scheme of sediment transport obtained by us. In general, this is not surprising, since the highest frequency in the area under consideration is observed for winds and waves of the southwestern direction, which, naturally, was reflected in the calculations performed by him for the prevailing wind over a long-term period. At the same time, the scheme of sediment transport proposed by Yu. D. Shuisky [12], according to which the resulting flow is directed towards Lake Donuzlav sandbar at the section of Cape Yevpatoriyskiy - sandbar of Lake Solenoye lagoon, is not partially confirmed. Moreover, the earlier ideas, according to which there is a single stream directed to the east, from Cape Uret to Cape Yevpatoriysky, are not confirmed either. We can agree that the part of the sediments in the secondary displacements go around Cape Yevpatoriysky and penetrate into the bay of the same name, which is confirmed by our calculations. 60 years ago V.P. Zenkovich wrote that the signs of the present significant transport of sediments in the area of Cape Uret - Cape Yevpatoriysky were absent. There are no visible signs of it at the present time as well. Direct observations at the sections and analysis of satellite images show that the variability of the coastal configuration on the decadal scale is associated with the accumulation of sediments in the coastal concavities and erosion of capes, and on seasonal scales - with temporary displacements caused by individual storms [13]. The latter can erode or, conversely, push the coastline up to a maximum of 25-30 m. Especially large changes occur in the areas where the sediments accumulate and their reserves on the beach and the underwater coastal slope are the greatest (to the southeast of Lake Donuzlav southern spit and near the sandbars of salt lakes), which indirectly confirms the results of mathematical modeling we obtained.

\section{Conclusion}

Based on the statistical analysis of the retrospective calculation results of wind waves for 1979-2018 and numerical modeling, the study of the wave regime and lithodynamic processes in the region of the accumulative shores of the Western Crimea in Cape Uret - Cape Yevpatoriysky section was carried out. The following main results were obtained:

for wave-generating directions, the south-west wind has the highest frequency (6\%). The long-term mean wind speed and significant wave heights are $7.3 \mathrm{~m} / \mathrm{s}$ and $0.87 \mathrm{~m}$, respectively; 
- the maximum values of the wind velocity are $24.5-25.9 \mathrm{~m} / \mathrm{s}$, the significant wave heights are $6.5-7.8 \mathrm{~m}$, the mean wave period is $11.2-11.4 \mathrm{~s}$;

- the most probable and wave-hazardous are the waves of the south-west and south-south-west directions;

- the most intense alongshore sediment flows in the area under study arise under effect of the waves generated by the winds of the western, southwestern and southern directions;

- at north-western and western winds, a general sediment flow, directed to the east, is formed. Under effect of the western wind, southeastwards of Lake Donuzlav sandbar in the concavities of the coast, the material displaces in the opposite direction;

- at southwestern and southern winds, the alongshore sediment flow is directed from Cape Uret to the northern spit of Lake Donuzlav, where it meets the flow of the opposite direction. To the south-east of Lake Donuzlav multidirectional alongshore flows occur, while the zones of their convergence are formed in the concavities of the coast;

- at southeastern and eastern winds the thickness of alongshore sediment flows sharply decreases, and they themselves are multidirectional, not forming a single flow on any extended section of the coastline;

- for the most wave-hazardous wind directions in the west - south sector, the model values of the specific sediment discharge are: at $7.5 \mathrm{~m} / \mathrm{s}$ wind velocity $10-25 \mathrm{~g} / \mathrm{m} / \mathrm{s}$ (at the coastal ledges $50-100 \mathrm{~g} / \mathrm{m} / \mathrm{s}$ ); at $10 \mathrm{~m} / \mathrm{s}$ wind velocity the sediment discharge is $200-400 \mathrm{~g} / \mathrm{m} / \mathrm{s}(700-800 \mathrm{~g} / \mathrm{m} / \mathrm{s}$ at the coastal ledges); at $15 \mathrm{~m} / \mathrm{s}$ wind velocity $-1-4 \mathrm{~kg} / \mathrm{m} / \mathrm{s}(5-6 \mathrm{~kg} / \mathrm{m} / \mathrm{s})$;

- an increase in the sediment flow discharge values on the underwater slope opposite the coastal protrusions and a decrease at the concavities leads to the material displacement and deposition in the coastal zone of the latter;

- the parameters of wind waves, which are possible once a year, in 5, 10, 25 and 50 years, are determined.

\section{REFERENCES}

1. Goryachkin, Yu.N. and Dolotov, V.V., 2019. Sea Coasts of Crimea. Sevastopol: COLORIT Ltd., 256 p. Available at: http://www.lib-mhi.ru/Download/Sea_coasts_of_Crimea.pdf [Accessed: 05 August 2020] (in Russian).

2. Goryachkin, Yu.N., 2018. Upwelling nearby the Crimea Western Coast. Physical Oceanography, 25(5), pp. 368-379. doi:10.22449/1573-160X-2018-5-368-379

3. Booij, N., Ris, R.C. and Holthuijsen, L.H., 1999. A Third-Generation Wave Model for Coastal Regions: 1. Model Description and Validation. Journal of Geophysical Research: Oceans, 104(C4), pp. 7649-7666. https://doi.org/10.1029/98JC02622

4. Divinskii, B., Fomin, V., Kosyan, R., Lazorenko, D., 2019. Maximum Waves in the Black Sea. In: E. Özhan, ed., 2019. Proceedings of the Fourteenth International MEDCOAST Congress on Coastal and Marine Sciences, Engineering, Management and Conservation. MEDCOAST 2019, 22-26 October 2019, Marmaris, Turkey. Ortica, Mŭgla, Turkey: Mediterranean Coastal Foundation. Vol. 2, pp. 799-810. 
5. Divinsky, B.V., Fomin, V.V., Kosyan, R.D. and Ratner, Yu.D., 2019. Extreme Wind Waves in the Black Sea. Oceanologia, 62(1), pp. 23-30. https://doi.org/10.1016/j.oceano.2019.06.003

6. Dzens-Litovskij, A.I., 1933. [The Bay-Bars and Spits of the Crimean Salt Lakes]. Izvestiia Gosudarstvennogo Geograficheskogo Obshchestva = Izvestia de la Société Russe de Géographie, 65(6), pp. 585-595 (in Russian).

7. Zenkovitch, V.P., 1947. A Study of Dynamies of the Scashous of West Cremea. Voprosy Geografii, (3), pp. 205-206 (in Russian).

8. Zenkovich, V.P., 1948. [The Structure of the Coast of Western Crimea near Evpatoria]. Voprosy Geografii, (7), pp. 179-186 (in Russian).

9. Zenkovich, V.P., 1960. Morphology and Dynamics of the Soviet Black Sea Coast. Vol. 2. Moscow: Izd-vo AN SSSR, 216 p. (in Russian).

10. Kos'jan, R.D., Pykhov, N.V. and Filippov, A.P., 1978. Vertical Distribution of the Concentration and the Composition of Suspended Material in the Wave Breaking Zone. Okeanologia, 18(6), pp. 1064-1069 (in Russian).

11. Dolotov, Y.S., Shadrin, I.F. and Yurkevich, M.G., 1971. [On the Dynamics of the Relief of the Underwater Coastal Slope, Folded by Shell Material]. In: V. P. Zenkovich, ed., 1971. [New Coastal Research]. Moscow: Nauka, pp. 110-119 (in Russian).

12. Shuisky, Yu.D., 2005. Basical Peculiarities of Morphology and Dynamic of the Western Crimea Peninsula Coast. In: MHI, 2005. Ekologicheskaya Bezopasnost' Pribrezhnykh i Shel'fovykh Zon i Kompleksnoe Ispol'zovanie Resursov Shel'fa [Ecological Safety of Coastal and Shelf Zones and Comprehensive Use of Shelf Resources]. Sevastopol: ECOSIGidrofizika. Iss. 13, pp. $62-72$ (in Russian).

13. Goryachkin, Yu.N., 2019. Interannual Variability of Coast Line of the Accumulative Western Crimea Coast (the Yevpatoriysky Cape - the Donuzlav Lake). Ecological Safety of Coastal and Shelf Zones, (3), pp. 25-36. doi:10.22449/2413-5577-2019-3-25-36 (in Russian).

14. Knaps, R.J., 1968. On Computations of the Power of the Sea Shore Sand Drifts. Okeanologia, 8(5), pp. 848-857 (in Russian).

15. Ignatov, E.I., 2010. [The Current State of the Black Sea Coastal Zone along the Southwestern Crimea]. Prichornomors'kiy Ekologichniy Byuleten' [Black Sea Ecological Bulletin], 1(35), pp. 60-73 (in Russian).

16. Longinov, V.V., 1966. [Review of Methods for Calculating Alongshore Sediment Movement in the Coastal Zone of the Sea]. Trudy Soiuzmorniiproekta, 14(20), pp. 40-41 (in Russian).

17. Ivanov, V.A. and Fomin, V.V., 2010. Mathematical Modeling of Dynamic Processes in the Sea - Land Area. Kiev: Akademperiodyka, 286 p.

18. Ivanov, V.A. and Mikhinov, A.E., 1991. [Forecast of Sediment Dynamics in the Coastal Zone of the Sea (Practical Recommendations and Examples of Calculations]. Sevastopol: MHI AN USSR, 50 p. (Preprint, in Russian).

19. Ivanov, V.A., Mikhinov, A.E., Luk'yanov, Yu.P., Baklanovskaya, V.F., Chechel', I.I. and Koveshnikov, L.L., 1993. [Dynamics of Sediments in the Coastal Zone of the Southern Coast of Crimea]. Sevastopol: MHI AN USSR, 36 p. (Preprint, in Russian).

20. Shuyskiy, Yu.D., 2007. Mechanical Composition of Beach Alluvium on West Coast of the Crimea. In: MHI, 2007. Ekologicheskaya Bezopasnost' Pribrezhnykh i Shel'fovykh Zon i Kompleksnoe Ispol'zovanie Resursov Shel'fa [Ecological Safety of Coastal and Shelf Zones and Comprehensive Use of Shelf Resources]. Sevastopol: ECOSI-Gidrofizika. Iss. 15, pp. 370-385 (in Russian). 
About the authors:

Yury N. Goryachkin, Senior Research Associate, Marine Hydrophysical Institute of RAS (2 Kapitanskaya Str., Sevastopol, 299011, Russian Federation), Dr. Sci (Geogr.), ORCID ID: 00000002-2807-201X, ResearcherID: I-3062-2015, yngor@mhi-ras.ru

Vladimir V. Fomin, Head of the Department of Computational Technologies and Mathematical Modeling, Marine Hydrophysical Institute of RAS (2 Kapitanskaya Str., Sevastopol, 299011, Russian Federation), Dr. Sci. (Phys.-Math.), ResearcherID: H-8185-2015, ORCID ID: 0000-00029070-4460, v.fomin@ukr.net

Contribution of the co-authors:

Yury N. Goryachkin - statement of the problem, review of lithodynamics of the study area, analysis of modeling results, preparation of the article

Vladimir V. Fomin - statement of the problem, carrying out numerical experiments, analysis of simulation results, preparation of the article

The authors have read and approved the final manuscript.

The authors declare that they have no conflict of interest. 